\title{
A comparative study of Blended learning versus Conventional learning in higher education on the academic achievement of undergraduate students in the general chemistry course
}

\author{
Najeh Rajeh Alsalhi ${ }^{a 1,2}$, , Heba Aboukhousa ${ }^{\text {b,1, }}$, Juhaina Tawfiq Omar ${ }^{\text {c,3 }}$, Rasha Abdelrahman ${ }^{\text {b,1,4 }}$, \\ Amel Beichi ${ }^{\mathrm{e}, 1}$
}

n.alsalhi@ajman.ac.ae, h.aboukhousa@ajman.ac.ae,jomar@mhs.sabis.net, r.abdelrahman@ajman.ac.ae,a.beichi@ajman.ac.ae

${ }^{1}$ College of Humanities and Sciences, Ajman University, Ajman, UAE

${ }^{2}$ Nonlinear Dynamics Research Center (NDRC), Ajman University, Ajman, UAE

${ }^{3}$ Ministry Military High School, UAE

${ }^{4}$ Researcher at National Center for Examination and Educational Evaluation, Egypt.

\begin{abstract}
The main goal of this study was to examine the impact of blended learning on the academic achievement of undergraduate students in the general chemistry (CHE101) course. The participants' learners of the study were (326) learners, who were randomly split into two groups, one of which taught by using blended learning (empirical group A, $\mathrm{n}=163$ ) and the other which with taught by using the conventional method (control group $\mathrm{B}, \mathrm{n}=163$ ). To accomplish the objectives of the study, the researchers prepared the study tool, which is an achievement test, after confirming its validity and reliability. Data analyses showed that there is a statistically significant difference among the mean scores of learners in the two study groups on the achievement test, for the benefit of empirical group learners, who taught through blended learning. Moreover, the results revealed that achievement varied according to the College of the learners in the empirical group (in favor of those students of Pharmacy and Health Sciences College). However, there is no statistically significant difference in students according to the students' gender variable and, according to the Academic year variable. The study recommended that blended learning be used more widely to cover different sectors of education.
\end{abstract}

Keywords:

Blended Learning, Conventional learning, chemistry Course (CHE101), academic achievement, higher education, undergraduate students.

Article Received: 18 October 2020, Revised: 3 November 2020, Accepted: 24 December 2020

\section{Introduction}

Education acts as a key role in the process of progress of nations and people so all nations in the world seek to attempt to develop their education. Therefore, educational institutions seek to find quality teaching methods that aim to generate active and positive students, and the teachers are guided in order to achieve the educational outcomes and are accomplished through mixing traditional education with elearning with its multiple types and technological and electronic innovations inside the classroom and outside it Mula (2015). So it is focused on two types of education are both conventional and e- learning together in the same time. Where the current twenty-first-century faces many changes in all areas of life, including the educational field. Where the emphasis in the field of education has moved to active learning for students, instead of merely transferring information, which means concentrating on the quality of education outcomes, which are directly connected to the goals of the constructivism theory in teaching and learning. According to constructivism theory, the learner builds his own knowledge through social interaction with others and the environment and builds his new knowledge based on previous knowledge and experience (Ayse, 2008). To 
achieve the goals of constructivism theory, a set of constructivist learning strategies have emerged that link technology to learning in accordance with structural philosophy and call for cooperative, collaborative learning and social interaction through which learners build their own knowledge (Y1lmaz \& Orhan, 2010). This is why the philosophy of blended learning emerged, which is an extension of classroom instruction over the Internet, provides educational institutions, such as universities and schools, with modern teaching methods and approaches to addressing the challenges they face and interesting new learning methods (Maccoun, 2016).

A number of academic researchers have reported that blended learning has emerged as a logical consequence of e-learning; as e-learning combines and integrates e-learning with conventional face-to-face classroom learning in a single learning model to gain the benefits and advantages of each and to achieve the desired objectives. In fact, e-learning or traditional education is not cancel e-learning or traditional education, but rather it is a mixture of both (Abidoye, 2015; Alzahrani and Toole, 2017; Graham, 2013; Elfaki, Abdulraheem and Abdulrahim, 2019; Moskal, Dziuban and Hartman, 2012; Sicilia, 2018; Wright, 2017). Moreover, it is one of the types of e-learning in which e-learning is merged with traditional education in one framework. Where e-learning tools, whether computer-based or network-based, are used for lessons, lectures, and training sessions, which are often conducted in real classrooms equipped with the ability to connect to the Internet or web (Sarıtepeci and Çakır, 2015; Shang, \& Liu, 2018; Yeou, 2016). Additionally, David (2016) and Trapp (2006) defined blended learning as widely integration of electronic teaching media with traditional teaching methods. Alvarez (2005) and Francis \& Susan (2013) highlighted the significance of blended learning, which integrates the benefits of conventional teacher-led learning and the advantages of information technology (IT) for the development of educational programs that include the content of the prepared scientific subject, web-based instructor, workshops, conferences, and live sessions with teachers on the Web. Therefore, a number of educators and experts believe that blended education may encounter resistance that hinders its success if it violates the course of the educational process. The teacher and the learner represent the basic components in addition to the educational curricula. Thus, in order for this to happen, the teacher must be able to use modern education techniques, as well as the student who must have the skills with the use of computers, the Internet, and e-mail that helps transfer this education to classrooms (Huang, 2002). Blended learning is among the most appropriate and innovative methods for university education to familiarize the learner with continuous learning to educate himself and enrich his information because the goal of university education is to develop critical and creative thinking skills, and provide them with methods of generating knowledge. Thus, the university student can continue his learning in the future (Oweis, 2018; Tongchai, 2016).

Milheim, (2006) and Valerie (2005) pointed out the most important features of blended learning like, education costs have decreased substantially compared to e-learning alone, Shift from lecture-style teaching to student-centered teaching, increase engagement between learners and instructors, learners with each other, and content, students, and resources external, increased access to information and knowledge. Moreover, Dangwal and Lata (2017) pointed to a comparison between blended learning and conventional learning, which was listed in table 1. Below. 


\begin{tabular}{|c|c|c|}
\hline Features & Conventional Learning & Blended Learning \\
\hline Application location & Fixed classrooms and not flexible & Any place and flexible \\
\hline Method of learning & Face-to-Face & Online and Face-to-Face \\
\hline Time of learning & Not flexible and at specific time & Time flexible and any time \\
\hline Usage of technology & Using technology not mandatory & Using the technology is necessary and mandatory \\
\hline Online support & None & Talks, submitting assignments online, assignments online \\
\hline Learning materials & Teacher & Teacher, Group of teachers \\
\hline Assignments & Individual, Group & Individual, Group \\
\hline
\end{tabular}

Table 1. A comparison between blended learning \& conventional learning

Moreover, Eduviews (2009) and David (2016) pointed out that blended learning can be implemented in the education sector like schools and universities utilizing a diverse range of models, Figure 1. Summarizes of these models.

\begin{tabular}{|c|c|c|}
\hline $\begin{array}{l}\text { Face-to-Face Driver Model } \\
\text { A face-to-face driver model is a form of } \\
\text { blended learning in which technology is } \\
\text { used together with traditional teaching to } \\
\text { improve and increase the academic } \\
\text { achievement of learners. }\end{array}$ & $\begin{array}{l}\text { Station Rotation Model } \\
\text { The Model in which students allows } \\
\text { to rotate on a fixed schedule or at the } \\
\text { teacher's discretion between learning } \\
\text { modalities, at least one of which is } \\
\text { online learning. }\end{array}$ & $\begin{array}{l}\text { Online Lab Model } \\
\text { The online lab model of blended } \\
\text { learning uses technology to deliver } \\
\text { most or all content. Students complete } \\
\text { most learning in the computer lab } \\
\text { housed in a traditional school. }\end{array}$ \\
\hline Self-Blend & Online-Driver Model & _The Flex Model \\
\hline $\begin{array}{l}\text { In this model, students take online } \\
\text { courses in addition to their traditional } \\
\text { face-to-face learning. }\end{array}$ & $\begin{array}{l}\text { By this model, Students study from } \\
\text { distant places and take courses, } \\
\text { instruction, and evaluation through } \\
\text { internet platforms. The role of Teachers } \\
\text { in this model as facilitators. }\end{array}$ & $\begin{array}{l}\text { Allows students to be flexible about their } \\
\text { schedules between learning activities, } \\
\text { according to their needs. Online learning } \\
\text { is considered the backbone of student } \\
\text { learning in the Flex model. }\end{array}$ \\
\hline
\end{tabular}

Figure 1: Blended Learning Models.

When looking at the educational institutions in the United Arab Emirates, we find that e-learning has been introduced to education in universities through the computerization of education. This was done via the introduction of elements of development based on modern technological methods in the educational system, as well as electronic networks, and the preparation of classrooms and virtual laboratories, in order to integrate these programs with the traditional system to improve learning outcomes. So the utilize of blended learning has become present in the classroom and accompanying both the teacher and student in Emirate Universities with ease to facilitate the process of education and to achieve educational goals. Each faculty member through the availability of these capabilities and services in universities can use it with his students hence; the researchers were interested in conducting this study.

David (2016) pointed out that numerous prior studies have already said that blended learning is earning significance in teaching and learning, particularly in university education.

Numerous studies have highlighted the significance of blended learning in the education 
system. It is noted from the check of previous studies that these studies have shown the efficacy of blended learning, which has contributed to the achievement of many educational benefits in the fields of academic, mental, psychomotor, and emotional skills. The achievement variable as a dependent variable has received the attention of many researchers in these studies due to its importance in changing the methods used in the teaching reality and its better reflection in the development of students' capabilities, skills, attitudes, encouragement and engagement for learning. The results of all studies indicated the positive impact of blended learning in the enhancement of academic achievement of the students. Several studies have highlighted the significance of blended learning in improving academic achievement, increasing motivation, and developing positive attitudes for learning mathematics and science as studies (Almasaeid, 2014; Harahap, Nasution, and Manurung, 2019; Kazu and Demirkol, 2014; Maccoun, 2016; Mondal, Majumder, and Mandal, 2019; Ocak and Topal, 2014; Mabuan and Ebron, 2017; Manguire, 2005; Qarariha, 2013; Seage and Türegün, 2020; Shaheen, 2008; Y1lmaz and Orhan, 2010). The importance of blended learning is demonstrated by what Al-Derbashi, Khaled \& Osama (2017) mentioned, that it helps increase the social interaction between teachers and learners and also achieves self-learning. Thus, the current study comes to examine the impact of using blended learning in the academic achievement of undergraduate students at Ajman University in a general chemistry course (CHE101).

\section{Study Questions}

Questions study in the current study were formulated as follows:

1. Is there a significant difference in the post-test mean scores of control group students and empirical group students in their academic achievement of the general chemistry course topics that they have learned?

2. Does the academic achievement of empirical students group that have learned through blended learning vary by gender, College, and academic year of the students?

\section{Significance of the study}

1- It comes in response to trends that call for attention to teaching methods and strategies that are really based on Constructivist theory

2- This study is agreement with the instructions of the UAE Ministry of Higher Education to the improvement of quality of education.

3- The members of the faculty encourage the utilize of blended learning in the educational process and contribute to developing a practical plan for training educators in higher education institutions to adopt this type of learning.

\section{Methodology}

\section{Participants}

The Participants in the present study were 326 undergraduate students enrolled in general chemistry course (CHE101), which is a mandatory course for all students of scientific colleges at Ajman University. They were split evenly into an empirical group of 163 students and a control group of 163 students. Figure 2 illustrated the participants' of study and Figure 3. Illustrated the demographics of the empirical group. 


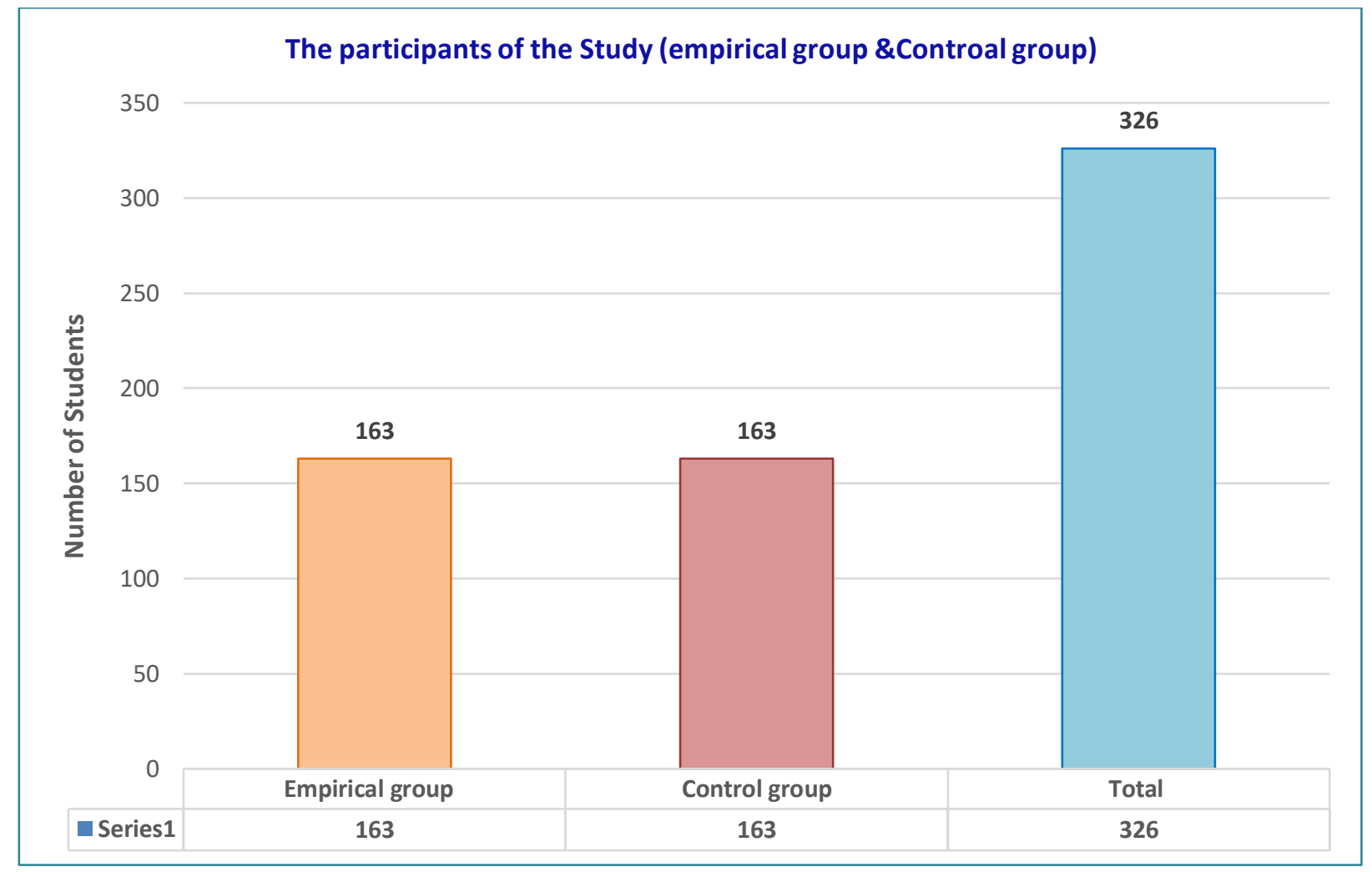

Figure 2. Participants of the study.

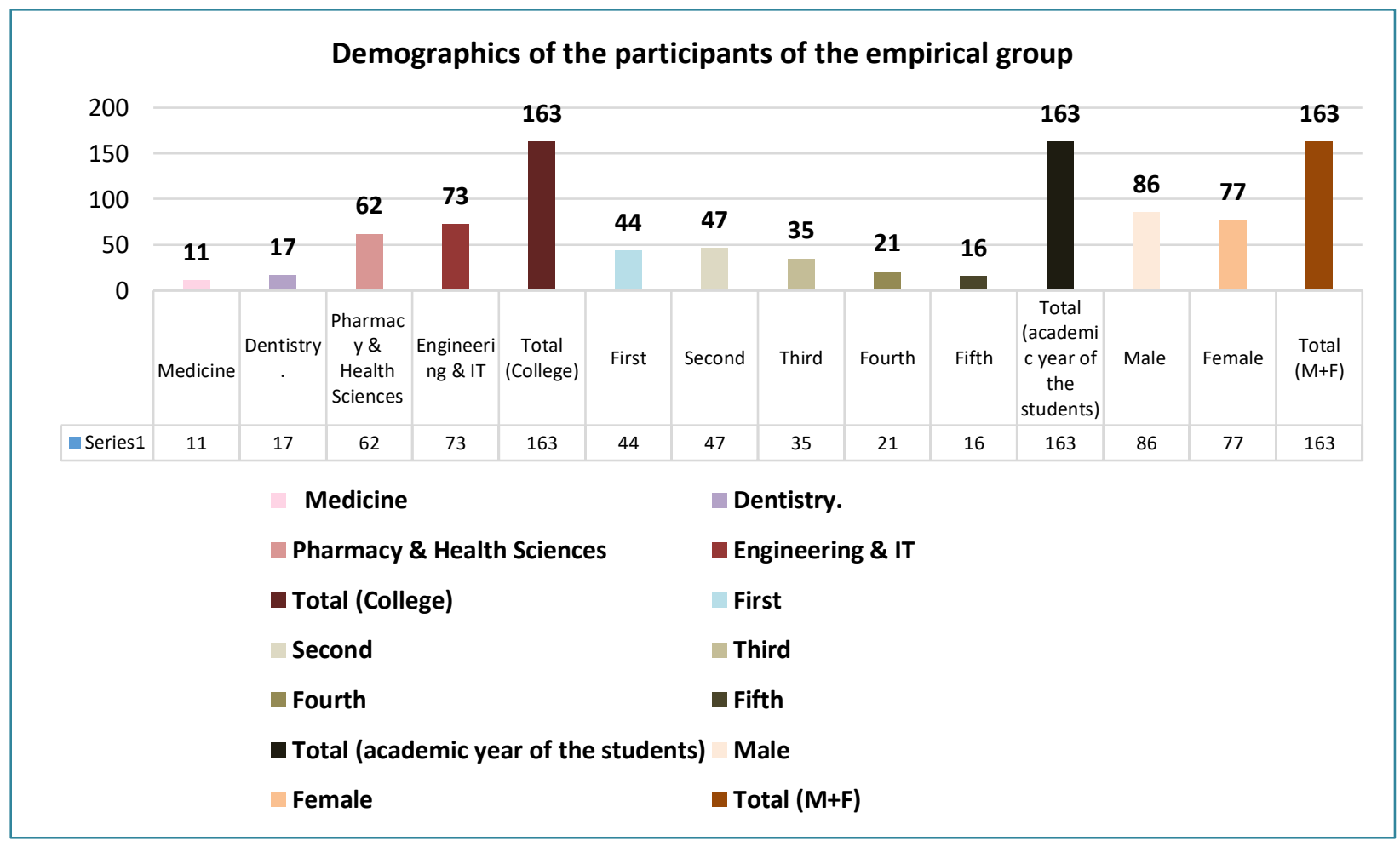

Figure 3. Demographics of the participants of empirical group.

\section{Study Approach}

Due to its appropriateness for the study's objectives, semi-experimental approach was used. In the current study, the researchers utilized two groups of students (Empirical group 163 students) and (control group 163 students). The topics of general chemistry (CHE101) course were taught to the students in the control group utilizing conventional learning, while in the empirical group the students were taught the same topics of 
the general chemistry course by utilizing blended learning. That implies that during the first term of the 2019/2020 scholar year, the two groups studied same topics through 10 weeks. Teaching topics are shown in Table 2:

Table 2. The learning topics of general chemistry course (CHE101)

\begin{tabular}{|c|l|c|}
\hline Week & \multicolumn{1}{|c|}{ Topics } & Number of lectures \\
\hline 1 & Atomic Electronic structure & 3 \\
\hline 2 & Quantum Mechanics & 4 \\
\hline 3 & The periodic table & 4 \\
\hline 4 & Types of bonds & 3 \\
\hline 5 & Molecular orbital Theory and Hybridization & 3 \\
\hline 6 & Introduction to organic chemistry & 4 \\
\hline 7 & Alkenes and alkynes & 3 \\
\hline 8 & Polymers & 2 \\
\hline 9 & Semiconductors & 2 \\
\hline 10 & Superconductors & 30 \\
\hline
\end{tabular}

\section{Study tools}

The investigators' study analyzed prior literature and studies pertaining to the study, such as studies (Davis, 2003; Epstein, 2007; Maccoun, (2016) and Mondal, Majumder, and Mandal (2019). Therefore, this study data depends mainly on Achievement exam, which is in detail as the following:

\section{Achievement test design}

The investigators' formulated achievement test to explore the impact of utilizing blended learning on student academic achievement in the general chemistry course. The test was designed in line with Bloom's cognitive domain taxonomy (Birlik, 2015; Brady, 2005; Hyder and Bhamani, 2016). Moreover, a specification table for this exam was designed (see Table 3 and Figure 4). The test consisted, in its finished product, of 20 MultiChoice questions. The question item earned one mark for a correct response and zero for incorrect response. Highest test scores were 20, and the test time was 90 minutes.

Table 3. Specifications for the test of the topics

\begin{tabular}{|c|l|c|c|c|c|c|}
\hline $\mathrm{N}$ & Topics & $\begin{array}{l}\text { No. } \\
\text { Lectures }\end{array}$ & $\begin{array}{l}\text { Topics Relative } \\
\text { Weight }\end{array}$ & $\begin{array}{l}\text { Lower } \\
\text { thinking Q }\end{array}$ & $\begin{array}{l}\text { Higher } \\
\text { thinking Q }\end{array}$ & Total Q \\
\hline 1 & $\begin{array}{l}\text { Atomic Electronic } \\
\text { structure }\end{array}$ & 3 & $10 \%$ & 1 & 1 \\
\hline 2 & Quantum Mechanics & 4 & $13.33 \%$ & 2 & 1 & -2 \\
\hline 3 & The periodic table & 4 & $13.33 \%$ & 1 & 1 & 2 \\
\hline 4 & Types of bonds & 3 & $10 \%$ & 1 & 1 & 2 \\
\hline 5 & $\begin{array}{l}\text { Molecular orbital } \\
\text { Theory and }\end{array}$ & 3 & $10 \%$ & & 2 \\
\hline
\end{tabular}




\begin{tabular}{|l|l|l|l|l|l|c|}
\hline $\mathrm{N}$ & Topics & $\begin{array}{l}\text { No. } \\
\text { Lectures }\end{array}$ & $\begin{array}{l}\text { Topics Relative } \\
\text { Weight }\end{array}$ & $\begin{array}{l}\text { Lower } \\
\text { thinking Q }\end{array}$ & $\begin{array}{l}\text { Higher } \\
\text { thinking Q }\end{array}$ & Total Q \\
\hline & Hybridization & & & 2 & 1 & 3 \\
\hline 6 & $\begin{array}{l}\text { Introduction to } \\
\text { organic chemistry }\end{array}$ & 4 & $13.33 \%$ & 1 & 1 & 2 \\
\hline 7 & Alkenes and alkynes & 3 & $10 \%$ & 1 & & 1 \\
\hline 8 & Polymers & 2 & $6.67 \%$ & 1 & & 1 \\
\hline 9 & Semiconductors & 2 & $6.67 \%$ & 1 & 2 \\
\hline 1 & Superconductors & 2 & $6.67 \%$ & $13(65 \%)$ & $7(35 \%)$ & 20 \\
0 & 30 & $100 \%$ & $100 \%)$ \\
\hline
\end{tabular}

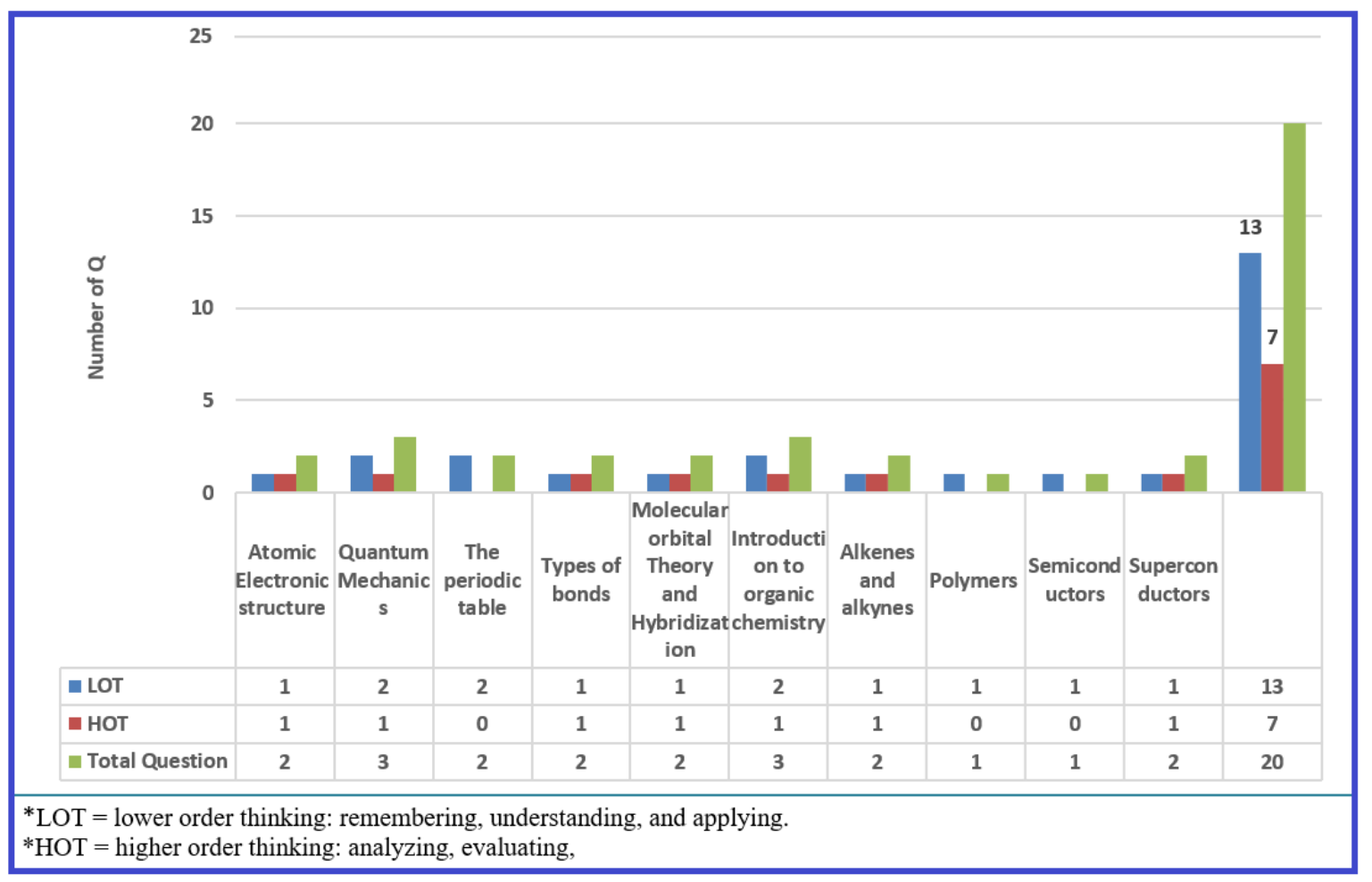

Figure 4. Specifications for the test of the topics

\section{Validity and Reliability of achievement test}

Achievement test was verified by presenting it, in its initial shape, as a valid virtual test method; Members of the academic staff of educational institutions whose doctoral and master's degree owners are in teaching and learning strategies. We removed a few of the questions and introduced others as recommended and suggested, even the test became valid. In addition, the researchers utilized the test-retest way to verify the reliability of the achievement test. It was re-applied on the same students' sample two weeks after the first test application. Afterward, the Pearson correlation coefficient among the two processes was determined, the overall reliability coefficient (0.853) deems acceptable for the study objective.

\section{Equivalence of empirical and control groups (Pre-test)}

To check the equivalence of participants between the students of the two groups studied. The 
researchersx utilized a t-test to compare the results of the pretest of the topics of the chemistry
(CHE101) course topics, before implementing the blended learning, as seen in Table 4, and Table 5:

Table 4. T-test of pre-test results of the two study groups

Table 4. Means and standard deviations of pre-test scores for two groups.

\begin{tabular}{|c|c|c|c|}
\hline Group & N & Mean & Std deviation (SD) \\
\hline Pre-test control & 163 & 11.77 & 1.79 \\
\hline Pre-test empirical & 163 & 11.55 & 1.83 \\
\hline
\end{tabular}

Table 5. T-test of pre-test results of the two study groups

\begin{tabular}{|c|c|c|c|c|c|c|}
\hline & \multicolumn{2}{|c|}{ Levene's Test } & \multicolumn{4}{c|}{ t-test } \\
\hline & $\mathrm{F}$ & $\mathrm{Sig}$. & $\mathrm{t}$ & $\mathrm{df}$ & $\begin{array}{l}\text { Sig. } \\
\text { tailed })\end{array}$ & $\begin{array}{l}\text { Mean } \\
\text { Difference }\end{array}$ \\
\hline $\begin{array}{c}\text { Equal variances } \\
\text { assumed }\end{array}$ & 0.020 & 0.888 & 1.071 & 324 & 0.285 & 0.2147 \\
\hline $\begin{array}{c}\text { Equal variances } \\
\text { not assumed }\end{array}$ & & & 1.071 & 323.894 & 0.285 & 0.2147 \\
\hline
\end{tabular}

As presented in Table 5, given that the $\mathrm{p}(0.285)$ extracted is larger than 0.05 , the test is not significant at a scale of 0.05 . This proves that there is no significant variation among the two study groups. Moreover, Table 3. Shown that the Mean of the two groups nearly the same value which was the values respectively (empirical group 11.55), (control group 11.77). This detects that the empirical group and the control group were identical before the implementation of the quasi-experimental method.

Preparing the educational chemistry course material

- The authors organized learning activities and presentations PPT for educating of Chemistry (CH101) topics course utilizing blended learning. The authors organized learning activities and presentations PPT of Chemistry (CH101) topics course. They utilized blended learning. In addition, the related multimedia, tasks, and pop quizzes found on the web link:

https://mylms.ajman.ac.ae/login/index.php

- Empirical Group given access to the Model of Learning for utilize in blended learning for the teaching. In meantime, topics were taught in the control group through face-to-face training in a school environment without utilize design of learning.

- Preparation of computer-based lessons for the topics of the chemistry (CHE101) course included multimedia, activities, tasks, and online quizzes and assignments.

- The researchers trained the empirical group students on how to access and utilize the educational materials on the Model of Learning system.

- All empiric group students signed in to the main page of the learning model system 


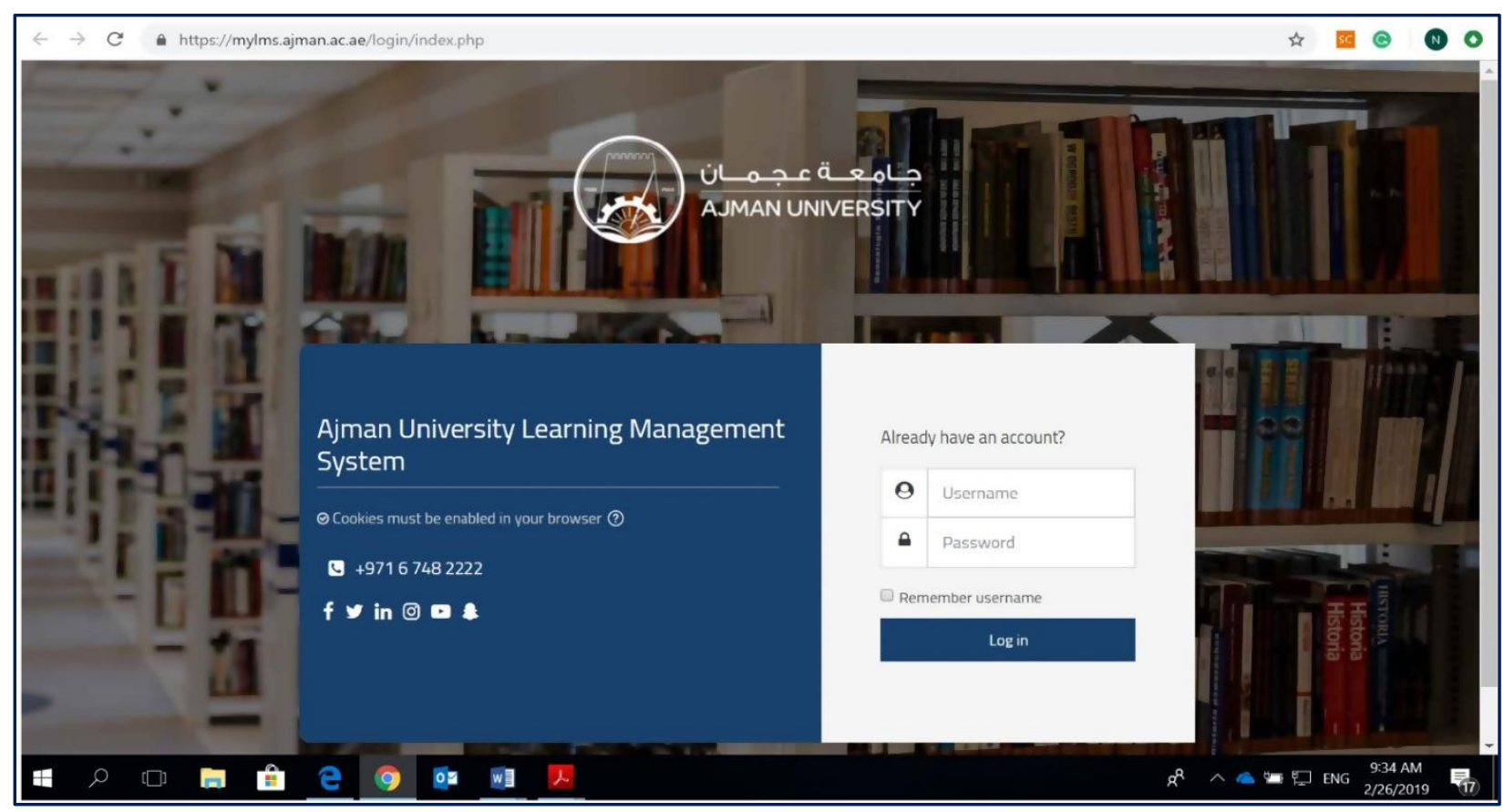

Figure 5: Homepage of Ajman University's Learning Management System Website

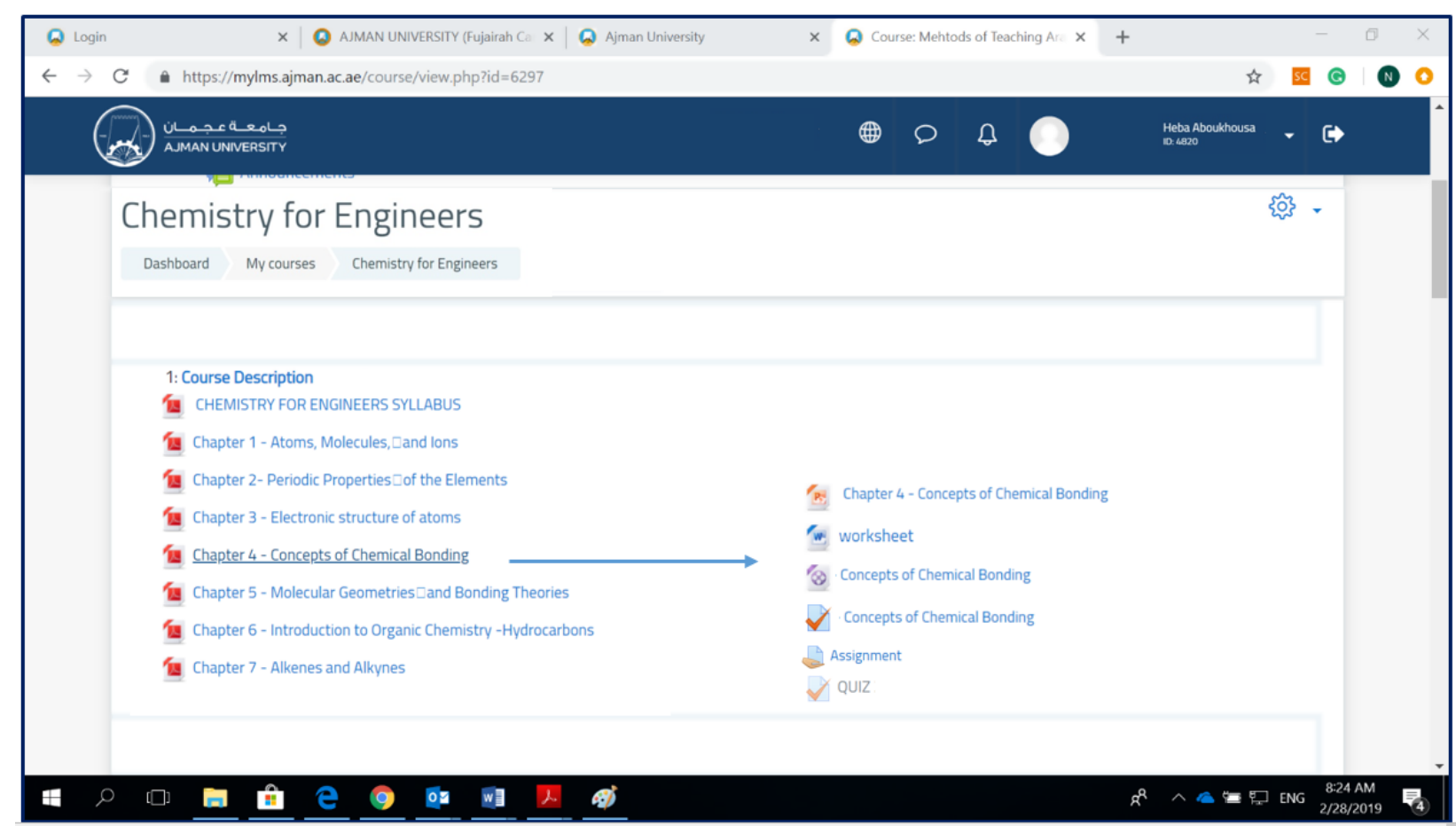

Figure 6. Course screen.

- Chemistry course topics screen as seen in Figure 6, For example, explains the learns chemical bonding and the related resources of this topic of the chemistry course.
- Empirical group students were quite engaged, more motivated, and critical video reviews were submitted.

- Achievement test designed in line with Bloom's cognitive domain taxonomy. 
- Students split into two groups: empirical group $(n=163)$ students' who have educated via blended learning and the control group $(n=163)^{\prime}$ who were educated via the conventional method.

- The application of teaching students in both study groups (empirical \& control group) began for a duration of 10 weeks.

- The post-test was implemented to the two groups (empirical and control), in order to investigate the impact of blended learning on the empirical group and comparing the result with the students of the control group.

- The investigators collected and analyzed the data using the SPSS program to derive findings and conclusions.

\section{Statistical processing methods}

The investigator used the SPSS software program to analyze the study data by performing a descriptive analysis, such as frequency calculation, average, and standard deviation (SD), including independent sample test (T-test). In addition, to the one-way ANOVA, and the LSD test.

\section{Findings}

\section{Findings of the study attributed to Question 1.}

RQ1: Is there a significant difference in the posttest mean scores between the control and empirical group students in their academic achievement of the chemistry (CHE101) course topics that they have learned?

The variance among the mean of students' scores in the empirical group that used the blended learning in their understanding topics of the chemistry (CHE101) course and the students of the control group that has not been used blended learning (conventional learning was used) was calculated. In addition, a t-test used for two independent samples as presented in Tables 6 and 7.

Table 6. Means and SD of post-test results.

\begin{tabular}{|c|c|c|c|}
\hline Group & N & Mean & SD \\
\hline Post-test control & 163 & 12.37 & 1.44 \\
\hline Post-test empirical & 163 & 17.67 & 2.00 \\
\hline
\end{tabular}

As seen in Table (5), the results refer that the students who were used the blended learning in their understanding the chemistry (CHE101) course, as appear in Table 5. The empirical group grades were different $(\mathrm{M}=17.67, \mathrm{SD}=2.00)$ from the control group of students $(M=12.37, \mathrm{SD}$ $=1.44)$.

Table 7. The independent sample t-test of post-test.

\begin{tabular}{|c|c|c|c|c|c|c|}
\hline & \multicolumn{2}{|c|}{ Levene's Test } & \multicolumn{4}{c|}{ t-test } \\
\hline & $\mathrm{F}$ & Sig. & $\mathrm{t}$ & $\mathrm{df}$ & Sig. (2-tailed) & Mean Difference \\
\hline $\begin{array}{c}\text { Equal variances } \\
\text { assumed }\end{array}$ & 3.364 & .068 & 27.451 & 324 & 0.000 & 5.2945 \\
\hline $\begin{array}{c}\text { Equal variances } \\
\text { not assumed }\end{array}$ & & & 27.451 & 294.664 & 0.000 & 5.2945 \\
\hline
\end{tabular}


As appear in Table 7, given that the p-value (0.000) is lower than 0.05 , this confirms there are significant differences at the significance level of 0.05 , which implies that there is a substantial difference among the two groups of participants in favor of the students of the empirical group. This implies based on the results of this T-test, it can be concluded that the use of the blended learning has a positive effect on understanding and increases scores students of the empirical group in the topics of the general chemistry course.

\section{Findings of the study attributed to Question 2}

RQ2: Does the academic achievement of empirical students group that have learned through blended learning vary by gender, College, and academic year of the students?

Average scores and standard deviations have been computed, the T-test used one-way ANOVA tests, and LSD tests were performed to determine the significance of average differences.

\section{Gender variable among students}

T-test utilized to assess the significance of the differences among Mean of scores of students of empirical group students, according to gender in terms of using blended learning, as indicated in table 8 .

Table 8. Means and standard deviations of the student answers based on Gender variable.

\begin{tabular}{|c|r|r|r|r|r|c|}
\hline Gender & N & Mean & SD & \multicolumn{1}{c|}{ df } & T. Value & Sig. (tailed) \\
\cline { 1 - 5 } Female & 77 & 17.81 & 1.52 & 161 & \multirow{2}{*}{0.364} & \multirow{2}{*}{0.716} \\
\cline { 1 - 5 } Male & 86 & 17.69 & 2.48 & 143.092 & & \\
\hline
\end{tabular}

The findings recorded in Table 7 illustrate that the observed $\mathrm{p}(0.716)$ is larger than 0.05 . Thus, the test in 0.05 scale is not significant, suggesting that there is no significant difference among the mean values for males and females in the students of empirical group.

\section{College variable among Students'}

The findings of the one-way ANOVA test of students' answers to this variable are appearing in Table 9.

Table 9: ANOVA test for student College variable.

\begin{tabular}{|l|l|r|r|r|r|r|}
\hline & & Sum of squares & df & Mean square & F & Sig. (tailed) \\
\hline \multirow{3}{*}{$\begin{array}{l}\text { Student } \\
\text { college } \\
\text { variable }\end{array}$} & Between Groups & 40.146 & 3 & 13.382 & & \\
\cline { 2 - 5 } & Within Groups & 661.032 & 159 & 4.157 & 3.219 & .024 \\
\cline { 2 - 5 } & Total & 701.178 & 162 & & \\
\hline
\end{tabular}

As presented in Table 9, the findings clearly illustrated that there are statistically significant differences in the academic achievement of empirical group students that have learned through blended learning according to variable of college, given that $\mathrm{p}$ is 0.024 , That it is less than the statistical significance level needed (0.05). Therefore, in order to identify the origin of the differences, the LSD test utilized for the next comparisons and the findings appear in Table 10 below. 
Table 10: LSD test findings for variable of College of the students'.

\begin{tabular}{|c|c|c|c|}
\hline (I) College & (J) College & $\begin{array}{l}\text { Mean Difference (I- } \\
\text { J) }\end{array}$ & Sig. \\
\hline \multirow{3}{*}{ Medicine } & Dentistry & -.027 & .973 \\
\hline & Pharmacy and health Sciences & -1.264 & .060 \\
\hline & Engineering and IT & -.375 & .571 \\
\hline \multirow{3}{*}{ Dentistry } & Medicine & .027 & .973 \\
\hline & Pharmacy and health Sciences & $-1.237-*$ & .028 \\
\hline & Engineering and IT & -.348 & .527 \\
\hline \multirow{3}{*}{$\begin{array}{c}\text { Pharmacy and health } \\
\text { Sciences }\end{array}$} & Medicine & 1.264 & .060 \\
\hline & Dentistry & $1.237^{*}$ & .028 \\
\hline & Engineering and IT & $.889 *$ & .013 \\
\hline \multirow{3}{*}{ Engineering and IT } & Medicine & .375 & .571 \\
\hline & Dentistry & .348 & .527 \\
\hline & Pharmacy and health Sciences & $-.889-*$ & .013 \\
\hline
\end{tabular}

The findings appear in Table 10 emphasize that the origin of the variations in in the academic achievement of empirical group students that have learned through blended learning according to the variable of college based on the variable of college arose from students with Pharmacy and health Sciences college.

\section{Academic year variable among Students'}

The findings of the one-way ANOVA test of students' answers to this variable are appearing in Table 11.

Table 11: One-way ANOVA test for student of Academic year variable.

\begin{tabular}{|l|l|r|r|r|r|r|}
\hline & & Sum of squares & df & Mean square & F & Sig. (tailed) \\
\hline \multirow{2}{*}{$\begin{array}{l}\text { Student } \\
\text { Academic } \\
\text { year variable }\end{array}$} & Between Groups & 4.670 & 4 & 1.168 & & \\
\cline { 2 - 7 } & Within Groups & 696.508 & 158 & 4.408 & 0.265 & 0.900 \\
\cline { 2 - 7 } & Total & 701.178 & 162 & & & \\
\hline
\end{tabular}

As presented in Table 11, the findings clearly illustrated that there are no statistically significant differences in the academic achievement of empirical group students that have learned through blended learning according to the variable of Academic year, given that $\mathrm{p}$ is 0.900 , That it is larger than the statistical significance level needed (0.05).

Discussion 
The results achieved in connection to the first research question about whether there is a significant difference in the post-test mean score between the control group and the empiric group of students' in their academic achievement of the chemistry CHE101) course topics that they have learned. Stated that there was a significant difference among learners in the empirical and control group in favor of students in the empirical group, who studied the chemistry topics course by using blended learning. The average score of students in the empirical group who utilized blended learning was 17.67 , compared to 12.37 for the students of the control group who not utilized blended learning and studied via conventional learning, as indicated in Tables 6.

Moreover, as shown in Table 7 , as the $\mathrm{p}$ value (0.000) obtained is less than 0.05 , this implies that there are significant differences at the significance level of 0.05 , which emphasizes the existence of a significant difference between the two groups of students that were studied. This indicates that utilizing blended learning had a positive impact on the empirical group students' academic achievement through their more depth understanding of the chemistry course topics that they have learned. The investigators may attribute this result to the positive features of a blended learning application in the teaching process, like flexibility, meet students' needs, and take into account individual differences between them. Eryilmaz (2015) refer that during blended learning a student can stop the lesson whenever he wants and watches it again at any time. Moreover, Students can view the lesson repeatedly within different times and periods. Seage and Türegün (2020) pointed out, that classroom activities and interaction with content and the teacher also motivate and encourage students to be more deeply think, which makes them more understanding of the topics of the academic content. Moreover, investigators may attribute the findings that blended learning has enabled students to interact directly in the classroom through the utilize of modern communication mechanisms such as computers and the internet, employing multimedia, and websites related to the topics of the lesson. Which enabled providing educational experiences closer to reality and providing an interactive environment that made students more active and interactive in the educational process. This results are consistent with previous studies (Ceylan and Kesici, 2017; Dangwal and Lalima, 2017; Harahap, Nasution, and Manurung, 2019; Kazu and Demirkol, 2014; Maccoun, 2016; Mondal, Majumder, and Mandal, 2019; Ocak \& Topal, 2014; Mabuan \& Ebron, 2017; Manguire, 2005; Qarariha, 2013; Seage and Türegün, 2020; Y1lmaz \& Orhan, 2010). The results of these studies have supported the significant impact of blended learning in the improvement of the academic achievement of the students. In addition, it indicated the significance of blended learning in increasing motivations, and developing positive attitudes for learning science like chemistry topics. The results of these studies also verified that blended learning made students be more motivated to learn, and developing positive attitudes towards learning courses of The results of these studies also verified that blended learning made students be more motivated to learn, and developing positive attitudes towards learning science courses like the chemistry topics.

The second study question concentrated on the investigation of whether the academic achievement of empirical group students that have learned through blended learning vary by gender, College, and academic year of the students. Our findings (illustrated in Table 7, 8, 9, 10 and 11) showed that students' of the empirical group varied according to the variable of college (in favor of those students of Pharmacy and health Sciences College). However, there is no statistically significant difference in students' according to the students' gender variable and, according to Academic year variable. Nevertheless, the findings of the study were not compatible with the findings of the study conducted by Yusoff, Md Noh, and Yusoff (2017) about the effect of blended learning on the science 
and mathematics courses and academic achievement of students in these courses. Where its results referred that, the post-test scores did not appear a significant difference between the empirical group and the control group, which indicates that the student scores in the post-test were close to each other.

\section{Conclusion:}

The level of quality education has become an essential criterion for the progress and growth of nations and societies around the world. Thus, the higher education institutions in the UAE are presently interested in developing learning strategies, techniques, and merge information technology (IT) into processes of learning, teaching, and instruction systems. The expansion of using IT, e-learning, and blended learning and its models in the learning and instruction system is one of the most essential goals in the higher education institutions in the UAE. This study seeks at examining the impacts of the use of blended learning on students' achievement in the general chemistry (CHE 101) course at Ajman University. The finding of this study revealed that using blended learning had a positive impact on increasing students' academic achievement in chemistry course topics. Where the data analyses confirmed that there were statistical differences between the empirical group students' and the control group students', in the benefit of the empirical group.

Moreover, results showed that students' of the empirical group varied according to the variable of College (in favor of those students of Pharmacy and health Sciences College). However, there is no statistically significant difference in students' according to the students' gender variable and, according to Academic year variable.

\section{Recommendations}

The study recommended the following:

1- Expanding the application of blended learning at universities and supplying all the materials needed for it.
2- Conduct similar studies on the implementation of blended learning.

\section{References}

[1] Alzahrani, M.G. and O'Toole, J.M. (2017). The Impact of Internet Experience and Attitude on Student Preference for Blended Learning. Journal of Curriculum and Teaching, 6(1), 65- 78.

[2] Al-Derbashi, Khaled Y., Abed, Osama H. (2017). The Level of Utilizing Blended Learning in Teaching Science from the Point of View of Science Teachers in Private Schools of Ajman Educational Zone, Journal of Education and Practice, 8, 193-205.

[3] Ayse, K. O. K. (2008). An online social constructivist tool: A secondary school experience in the developing world. Turkish Online Journal of Distance Education, 9(7), 87-98.

[4] Birlik, S. (2015). Taxonomy of the cognitive domain: An example of architectural education program.

Procedia - Social and Behavioral Sciences 174, $3272-3277$

[5] Eryilmaz, M. (2015). "The Effectiveness of blended learning environments", Contemporary Issues in Education Research, - 4th Quarter 2015, Vol. 8, No. 4.

[6] Brady, A. (2005). Assessment of learning with multiple-choice questions. Nurse Educ. Pract. 5, 238 -242.

[7] Ceylan, V. and A. E. Kesici. (2017). Effect of Blended Learning to Academic Ahievement. Journal of Human Sciences. (14).

[8] Dangwal, K. and Lalima (2017). Blended Learning: An Innovative Approach. Universal Journal of Education Research 5 (1): 129-136. 
[9] Davis, M. H. (2003). Outcome Based Education. Journal of Veterinary Medical Education, 30 (3), 227-232.

[10] David, M (2016). Situational Leadership Theory as a Foundation for a Blended Learning Framework، Journal of Education and Practice, 7, 25-30.

[11] Elfaki, N., Abdulraheem, I. and Abdulrahim, R. 2019. Impact of e-learning vs traditional learning on student's performance and attitude. International Journal of Medical Research and Health Sciences, 8(10), pp.76-82.

[12] Epstein, R. M. (2007). Assessment in medical education. New England Journal of Medicine, 356 (4), 387-396.

[13] Francis, R. \& Susan, J. S. (2013). Engaging with blended learning to improve students' learning outcomes. European Journal of Engineering Education. 4, 359-369

[14] Graham, C. R. 2013. Emerging practice and research in blended learning. In M. G. Moore, ed. 2013. Handbook of distance education (3rd ed.). New York, NY: Routledge. pp.333-350.

[15] Huang, H. (2002). Toward constructivism for adult learners in online learning environments. British Journal of Educational Technology, 33(1), 27-38.

[16] Harahap, F., Nasution, N., Manurung, B. (2019). The Effect of Blended Learning on Student's Learning Achievement and Science Process Skills in Plant Tissue Culture Course. International Journal of Instruction, $12(1), 522-538$.

[17] Kazu, I., Demirkol, M., 2014. Effect of blended learning environment on high school students' academic achievement. Turkish Online J. Educ. Technol., 13(1), 78-87.
[18] Moskal, P., Dziuban, C. and Hartman, J. 2012. Blended learning: A dangerous idea? The Internet and Higher Education, 18, pp.15-23. DOI: 10.1016/j.iheduc.2012.12.001.

[19] Maccoun, Hussein Salem. (2016). The Effect of Using Blended Learning on the Achievement of Students and Information Retention of Fifth Graders in the Biology Course. Faculty of Education Journal, 22 (95) 209-240.

[20] Mabuan, R. and Ebron, G. (2017). A blended learning approach to teaching writing: using e-mail in the ESL. The Asian EFL Journal Professional Teaching. (100), 80- 103.

[21] Mondal, G., Majumder, P., and Mandal, M. (2019). Effect of blended learning strategy for secondary school science students. International Journal of Research and Analytical Reviews, 6 (1), 381- 387.

[22] Milheim, W. D. (2006). Strategies for the Design and Delivery of Blended Learning Courses. Educational and Delivery Technology, 46 (6).

[23] Manguire, K. (2005). Professional development in blended e-learning environment for middle school mathematics teachers. M. A. dissertation, Canada, University of Toronto.

[24] Mula, J. (2015). Effects of E-Blended Instruction on Grade 10 Students Performance and Attitude towards Geometry. Trece Martires City National High School

[25] Oweis, T. (2018). Effects of using a blended learning method on students' achievement and motivation to learn English in Jordan: a pilot case study. Education Research International, online. DOI: 10.1155/2018/7425924.

[26] Ocak, M. \& Topal, A. (2014). A blended Learning Approach To Motivation of Medical students Taking Anatomy 
class. International Journal on New Trends in Education and Their Implications, 5 (3), 90-103.

[27] Shang, F., \& Liu, C.-Y. (2018). Blended learning in medical physiology improves nursing students' study efficiency. Advances in Physiology Education, 42(4), 711-717.

[28] Seage, S.J., \& Türegün, M. (2020). The effects of blended learning on STEM achievement of elementary school students. International Journal of Research in Education and Science (IJRES), 6(1), 133-140.

[29] Sicilia, N. (2018). Blended learning: the new normal and emerging technologies. International Journal of Educational Technology in Higher Education, 15(1), 116.

[30] Sarıtepeci, M. and Çakır, H. (2015). The effect of blended learning environments on student's academic achievement and student engagement: a study on social studies course Education and Science, 40 (177), pp.203-216.

[31] Trapp, S. (2006). Blended Learning concepts - a short over view. Innovative Approaches for Learning and knowledge sharing, EC- TEL Works Shops proceedings, ISSN 1613-0073, 28-

35.

[32] Tongchai, N. 2016. Impact of selfregulation and open learner model on learning achievement in blended learning environment. International Journal of Information and Education Technology, 6(5), pp.343-347

[33] Valerie, J. (2005). The effectiveness of blended Learning for the employees, dissertation. Unpublished. Fiflding Gradvate University.

[34] Wright, B. M. (2017). Blended Learning: Student Perception of Face-To-Face and Online Efl Lessons. Indonesian Journal of Applied Linguistics, 7(1), 64.
[35] Yeou, M. (2016).An Investigation of Students' Acceptance of Moodle in a Blended Learning Setting Using Technology Acceptance Model. Journal of Educational Technology Systems, 44, $300-318$

[36] Yilmaz, M.B. \& Orhan, F. (2010). Preservice English teachers in blended learning environment in respect to their learning approaches. The Turkish Online Journal of Educational Technology -TOJET, 9(1), 157-158.

[37] Yusoff, R., Md Noh, N., and Yusoff, S. (2017). A blended learning module for a course in statistics. International Journal of Learning in Higher Education, 4 (5), 1-10. 